\title{
The innovation of the ideological and political education in the era of media convergence
}

\author{
Xinping Wang ${ }^{1, a}$ \\ ${ }^{1}$ Jiangxi Institute of Fashion Technology, Jiangxi, Nanchang, 330201 \\ a149139978@qq,com
}

Keywords: College students; The ideological and political education; Media convergence; innovation

\begin{abstract}
College students' ideological and political education as an important part of university education, is to train socialist builders and successors, ensure the all-round construction of a harmonious socialist society, to speed up the development of social economy and culture of our country has important significance. Along with our country the development of media technology, new media and traditional media gradually merging, thus widely on the ideology and values of college students, the influence of it to the ideological and political education of college students has brought new opportunities and challenges, how to in the era of media convergence, the correct use of media, media, the mass media should play the role of guidance, innovative ideas and methods of ideological and political education, is an urgent problem in the ideological and political education. In this paper, the brief analysis of media convergence challenges and opportunities for college students' ideological and political education, puts forward the era of media convergence strategy of the innovation of ideological and political education, so as to provide reference for college students' ideological and political education work.
\end{abstract}

\section{Introduction}

With the development of information technology and Internet technology, the increasingly rich media resources in our country, there was represented by the Internet network media, mobile media, weibo, WeChat, SNS, search engine and other emerging media, these new media has become a modern college students of popular media, the rapid development of new media to make China's traditional media has been challenged, but also promoted the fusion between the two. Emerging media open, innovative and interactive for college students not only provided a broad space for development, but also increase the difficulty of the spread of bad information regulation, inevitably on college students' values and ideology have a negative impact, which brings serious challenges for the development of college students' ideological and political education. In the context of media convergence, the innovation of the ideological and political education in colleges and universities must constantly teaching form, the comprehensive media integration under the background of the problems faced by college students' ideological and political education work, continuously enrich the teaching concept, improve the level of college students' ideological and political education work.

\section{Media convergence of ideological and political education for college students to provide opportunity}

The openness of the media resources. Emerging media, relying on Internet technology, increase the openness of all kinds of resources, accelerated the speed of the spread of information, at the same time for college students to get all kinds of resources to provide more convenience. Have a huge database of Internet technology, people can at any time, anywhere on the Internet to obtain the required all kinds of resources, the ideological and political education workers, but also more convenient access to the classroom the required material or data, to the introduction of the hot topics and current affairs and political class, make the class more interesting, to enrich the content 
of classroom teaching.

The media resources sharing. The emergence of new media broke the limitation of resources sharing, thus greatly improving the ideological and political education resources utilization. Due to the limitation of various factors, traditional media information can be collected to save or share, such as patriotism education, college students within the prescribed time, place, listening to lectures, education workers to explain the knowledge of the lectures, thought cannot be saved. Emerging media make resource sharing is not restricted by time, so the ideological and political education workers can access to the latest global marxist theory of related studies and reports, and to study and summary, continuously accumulate the experience of ideological and political education, to strengthen the ideological and political education of college students.

The vitality of the new media technology for the reform of the college students' ideological and political education to bring inspiration and vitality. The traditional ideological and political education work in our country, in the form is too single, dull and boring, through teacher's explanation or open seminars, in the form of a lack of convince, students accept more difficult. New media in the process of transmission, image is more lively, intuitive, can attract the interest of college students, to further improve the classroom teaching efficiency. College students' ideological and political education work, therefore, should pay attention to the rights of college students' independent choice, make university students have volunteered to accept the ideological and political education, to the students, give full play to the advantages of new media. In addition, the college students' ideological and political education workers should be in-depth reflection, combined with the traditional way of ideological and political education, method, constant innovation.

The medium fusion offers a new challenge for ideological and political education

Large amounts of information quickly spread increases the difficulty of the regulation. The era of media convergence, the spread of information increasing in number, speed is accelerated, the scope of spread more widely than before, the transmission of information faster than traditional media, so the network information control more difficult. Rapid spread of information makes the ideological and political education workers can timely grasp the students' learning dynamic, and the openness of its content result in mud and sand flow together at the same time, due to the lack of corresponding legal constraints in our country, result in an increase in the spread of bad information control difficulty of colleges and universities. Once the wrong information spread among college students, its propagation speed is very fast, can quickly become a hot topic of network media, and combined with some bad information misleading, are college students values distortions.

Of the media convergence time easy to cause the student to rely too much on virtual space. Under the background of the traditional media era, college students always receive information in a passive position, and information are also acceptable after certain screening, control, so rarely can cause bad influence on college students' ideology. The emergence of new media makes a lot of uncontrolled rapid spread of information, especially some emerging media rich entertainment atmosphere, easy to cause college students to rely on the virtual space. Now college students during the class will use weibo, WeChat and some other social software to chat, the serious influence classroom learning atmosphere, in addition some network game, network platform will provide enough space for college students, in which speak freely, but real life is depressed, divorced from reality.

Of the era of media convergence "since the media trend" the integration of ideological restricted.With the development of new media and the fusion of two forms of media, make our country a large number of "media", the creator of these since the media is an independent source of all, the type of information of all kinds. Setting advanced technologies easy to cause the emergence of personal extremism, resulting in the lost of the undergraduates' values, error values, even cause the college students' political consciousness, it also increases the difficulty of the integration of independent ideology of colleges and universities, so as to make college students' ideological and political education work more difficult.

Under the age of three, media fusion the innovation of the ideological and political education 
work

Media convergence is an inevitable trend in the development of information technology, although it is still in the stage of development is not perfect,, but it will gradually specification. So the ideological and political education workers in colleges should make full use of modern media integration advantages, advancing with The Times, continuous innovation of the ideological and political education method, promote the steady development of the ideological and political education work.

Make full use of media resources, in the form of innovation of ideological and political education work. Under the traditional media, the ideological and political education work due to the information channel, transmission speed, and the limitation of transmission, the teaching goal is generally difficult to achieve. Under the background of media convergence, the university ideological and political education more liberalisation, decentralized, more vivid, interactive, the concept of ideological and political communication effect is better, students are more likely to accept. Under the background of media convergence, the ideological and political education workers should make full use of the resources of media convergence, and the values of college students, demand as well as the attention, mental state, the premise of complex factors such as personal experience as a respected factors, establish an object holographic data system, and on this basis, the choice of teaching contents, teaching methods to and improvement, constantly enrich the content and forms of classroom teaching, make the class more interesting, make teaching content more press close to practice, life and the populace.

Use of media convergence medium, to develop the network of ideological and political education. Under the background of media convergence, can use the media also increased than before, such as computers, smart phones to develop network ideological and political education form provides a convenient, ideological and political education workers by WeChat, weibo, QQ and other social software or other information exchange platform for teaching, more likely to be accepted by the college students. College students' ideological and political education workers should make full use of various media, and build a variety of forms of network ideological and political education publishing platform, according to the actual circumstance of contemporary college students' psychological state and timely update news, let students form the habit of contact network ideological and political education is energy, resist complex thoughts under the environment of negative thoughts, form a positive outlook, values, outlook on life.

The advantage of rich media integration platform, the ideological and political education form of cultural transmission. Ideological and political education is a profound and rich connotation, theoretical strong, full of inner energy and potential energy of the subject, in the context of media convergence, the ideological and political education for the broad platform for the cultural transmission, the ideological and political education workers should use media integration platform, and adopt various forms to college students to spread the value of the harmonious culture and professional culture, morality, political belief, cultivate college students' political sensitivity, enrich the ideological and political education form of cultural transmission.

Using the medium fusion as a clear the responsibility sharing of ideological and political education. Media integration to promote the development of the information society, but at present, the lack of corresponding management mechanism, and the media self-discipline consciousness has not yet reached the corresponding level, the media is not yet clear his own social responsibility. With the continuous development of socialism in our country, the media should be fully clear their social responsibility, conscience, the bottom line, adhere to and maintain the socialist core values, to resist the spread of bad information. As college students' ideological and political education of university teachers should bear an important responsibility of the education, more serious, responsible, contact bad information on the correct guidance for college students, make students establish the correct values.

\section{Conclusion}

In conclusion, media convergence to the ideological and political education has brought new 
development opportunities, but also for the college students' ideological and political education work brings serious challenges, the ideological and political education workers should fully grasp and use of media convergence, the innovation teaching method, improve the quality of college students' ideological and political education work.

\section{Reference}

[1] Ye Shen. New media age ideological and political education value concept innovation research [J]. Journal of ethics research, 2014,01:131-134.

[2] wang yu, Zhang Shujun. Media convergence in the environment of ideological and political education form innovation research [J]. Journal of social science in guangxi, 2014 01:189-192.

[3] Cao Shan. Under the new media era, the ideological and political education work is facing the opportunities and challenges [J]. Journal of jiamusi vocational college journal, 2014, 10:40 + 42 .

[4] YiJun Zou Jincheng, er-ping luo, Zou Tingyuan. Theory of ideological and political education and college students' innovative undertaking education of the organic fusion [J]. Journal of ideological and theoretical education Tribune, 2014, 12:92-94.

[5] chan poem. Media convergence trend under the present situation and countermeasures of college students' ideological and political education research [J]. Journal of intelligence, 2013, 22:121. 